\title{
CSR Disclosure, Corporate Governance and Firm Performance: A Study on GCC Islamic Banks.
}

\author{
Mohd Shukor Harun ${ }^{\mathrm{a}}$ \\ Khaled Hussainey ${ }^{\mathrm{b}}$ \\ Khairul Ayuni Mohd Kharuddin ${ }^{c}$ \\ Omar Al Farooque ${ }^{\mathrm{d}}$ \\ ${ }^{a} U n i v e r s i t i$ Sains Islam, Malaysia \\ bPortsmouth University,United Kingdom \\ cLoughborough University,United Kingdom \\ ${ }^{d}$ University of New England, Australia
}

\begin{abstract}
:
This study explores the CSR disclosure practices of the Islamic banks in the Gulf Cooperation Council (GCC) countries during the period 2010- 2014 and examines the determinants of CSR disclosure and its effects on the firm value. Developing a comprehensive CSR disclosure index based on Accounting and Auditing Organization for Islamic Financial Institutions (AAOIFI) Governance Standard No. 7 guidelines and using content analysis, the study shows a very low level of CSR disclosure among the sample Islamic banks. Again, using corporate governance characteristics to examine the determinants of CSR disclosure and applying the ordinary least square regression, it provides evidence of a significant positive association between board size and CSR disclosure practice in Islamic banks, while negative significant relationship of CEO duality with CSR disclosure, as per expectation. To examine the economic consequences of CSR disclosure, the study documents an inverse performance effect of CSR disclosure, while board size, board composition and CEO duality have significant positive effect on firm value. These results instigate the global debate on the need for corporate governance reform in Islamic banks by providing insights on the role played by corporate governance mechanisms in encouraging and enhancing CSR disclosure practice among Islamic banks. The findings also have important implications for investors, managers, regulatory bodies, policy makers and Islamic banks in the GCC countries.
\end{abstract}

Keywords: Corporate social responsibility disclosure, Corporate governance, Firm value, Accounting and Auditing Organization for Islamic Financial Institutions, Gulf Cooperation Council, Islamic banks 


\section{Introduction}

The recent development of corporate social responsibility (CSR) has enormous impact on the role of business that resulted in the change of accounting practices (Aribi and Gao, 2010). CSR disclosure plays a significant role in business, including enhancing corporate transparency, developing corporate image, and providing useful information for investment decision-making (Gray et al., 1988; Friedman and Miles, 2001). The rising importance of CSR has also reflected in academic research (Plumlee et al, 2009; Johansen, 2010). Nowadays, companies are seen as organisations that operate within the society having responsibility to ensure socio-economic justice and, at the same time extend benefits to the stakeholders including shareholders (Mohammed, 2007), consistent with the stakeholder theory perspectives. As the banks realise the significance of stakeholders financial anticipation, the role of CSR disclosure has become more important as a means of discharging accountability (Gray et al., 1996; Park and Ghauri, 2014). The pressure on companies to be accountable to a wider audience of stakeholders is coming from a number of sources such as the ethical investors, consumer associations, a growing number of pressure groups and United Nations and European Community Directives (Gray et al., 1988). When firms discloses CSR activities, they discharge accountability to a broader spectrum of stakeholders rather than shareholders alone. Such disclosures provide insights beyond those conveyed in financial disclosures and can help diminution of the information gap, enhance the credibility of corporate reporting, and add to empathetic the role of accounting information in firm valuation. While Klein et al (2005) have documented the consequences of disclosure on firm value, Pagano et al. (2002) content that disclosure is a mechanisms that allow investors to increase their ability in firm' monitoring as well as enhancing firm value.

The development of the agency theory has resulted in the implementation of governance structures whereby the control of decisions is separated from the management (Fama and Jensen, 1983). Prior studies have used the theoretical framework of the agency theory to test hypotheses concerning with the extent of disclosure to corporate governance characteristics (Xiao and Yuan, 2007). Gul and Leung (2004) argue that the role of corporate governance on the agency relationship between managers and stakeholders can best be examined by looking at several governance mechanisms. Numerous studies that examined the factors affecting disclosure

suggested that corporate governance and firm characteristics are the key drivers for corporate disclosure level, either as a whole (Samaha et al., 2015; Gisbert and Navallas, 2013; Farook et al., 
2011; Bhatti and Bhatti, 2009) or for different types of disclosure (Elshandidy et al., 2013; Abraham and Cox, 2007). Therefore, corporate governance mechanisms can be considered as essential factors illustrative to the decisions of corporate disclosure related to CSR from agency and stakeholder theory perspectives. Other streams of research also shows that disclosure reporting plays an important role in improving communication with stakeholders along with a positive impact on the firm value (Uyar and Kilic, 2012; Anam et al., 2011; Wang et al., 2008; Schwaiger, 2004; Hassan et al., 2009; Servaes and Tamayo, 2013). In fact, the association between disclosure and firm value is adequately explained the signaling theory in the sense that comprehensive disclosure signals better governance mechanisms, therefore leading to higher firm value.

The growth of Islamic banking and financial system has been one of its hallmarks since its inception in $1975^{1}$ and its market capitalisation currently stands at USD \$2.05 trillion (IFSB, 2018). Despite its growth, it is believed that Islamic banking represents the absolute ethical codes of Islamic religion because of the unique characteristics of Islamic finance - no interest (riba), prevention of uncertainty (gharar) and gambling (maysir) and the insistence of 'real' transactions (El-Gamal, 2005). In fact, the Islamic codes impose strong social obligations on Muslim individuals and organisations (Maali et al., 2003). From the Islamic perspective, CSR represents accountability to God (Allah) and then accountability towards society/stakeholders (El-Halaby \& Hussainey, 2015), therefore, they can be interpreted as institutions, which promote social justice and social responsibility (Maliah, 2000). In the Islamic context, social responsibilities represent the concept of brotherhood "ukhuwah" from one to another. As such, the social role is very important for Islamic banks and they can be described as banks who have a social face towards the society (Haniffa and Hudaib, 2007; Al-Mubarak and Osmani, 2010; Hasan, 2011). Consequently, as Islamic banks that operate in Islamic principles, they should be more active on promoting CSR and accountable towards stakeholders and society in general. Based on the accountability principles, Islamic banks are required to disclose all information that reflect their identity (Bayoud et al., 2012). It is expected that Islamic Banks disclose CSR information in a succinct, truthful and comprehensible method to meet their stakeholder's needs (Haniffa and Hudaib, 2007) as well as enhance their transparency and improve ethical behaviour (Case and Alqadi, 2012). The Accounting and Auditing Organization for Islamic Financial Institutions

\footnotetext{
${ }^{1}$ Institutions offering Islamic financial services started emerging in 1960 in isolation, the real momentum of Islamic banking and finance started in 1975 with establishment of Dubai Islamic Bank and the Jeddah Islamic Development Bank (Ayub, 2007).
} 
(AAOIFI) also reiterates that Islamic banks should disclose all information necessary to inform the community about their operations affecting the community wellbeing (AAOIFI, 2010).

The existing body of the CSR literature in Islamic banks focuses on either the level of CSR disclosure (Hassan and Harahap, 2010; Aribi and Gao, 2012) or the determinants of CSR disclosure (Farook et al., 2011; Amin et al. 2011; Rahman and Bukair 2013). However, prior studies have not provided evidence on the factors determining CSR disclosure for Islamic banks in the Gulf Cooperation Council (GCC) countries. Again, most of previous studies are conducted before the issuance of an updated AAOIFI Governance Standard No. 7, not represents a clear benchmark of CSR disclosure practice in Islamic banks. The motivation behind this study derives from the dearth of research on CSR disclosure in Islamic banks in GCC countries after the issuance of AAOIFI's Governance Standards no. 7 in 2010. In fact, only a handful studies adopts AAOIFI as a best practice for CSR reporting for Islamic Banks based on the latest AAOIFI overnance standards versions, $2010^{2}$ which provides variations of CSR disclosure practices between banks and countries. Also, prior studies (Case and Al-qadi, 2012; Maali et al., 2006) have not clearly examined how CSR reporting could influence a firm's value for GCC Islamic banks. This study aims to bridge the research gap by exploring the CSR disclosure practice among the Islamic banks in GCC and then examining its determinants and consequences (firm value).

This study contributes to the existing disclosure literature in a number of ways, firstly, in fulfilling prior research gap, it explores the CSR disclosure score of Islamic banks in GCC. Unlike prior research, this study also enhances the understanding of the factors explaining the crosssectional variation in the quantity of the information disclosed by Islamic banks using the benchmark develop based on AAOIFI standards no 7. Expending an integrated CSR framework, it investigates the extent to which corporate governance mechanisms explain the variations of CSR practice in GCC Islamic banks. To the best of knowledge, no other studies attempted this. This study differs from previous studies (Maali et al., 2003; Thompson and Zakaria, 2004; Hussainey, 2011; Mallin, Farag and Ow-Yong, 2014; Rahman \& Bukair, 2013; Platonova, 2013), which also discuss the issue of CSR disclosure by narrowly focusing on GCC perspectives. Therefore, developing a comprehensive disclosure index and using AAOIFI governance standards, the study provides an insight on CSR disclosure practice among Islamic banks in the GCC region, which is

\footnotetext{
${ }^{2}$ From the researcher knowledge there is no updated of governance standards which relate to CSR disclosure practice in AAOIFI, 2014.
} 
supported by prior research (e.g. Haniffa and Hudaib, 2007; Platonova, 2014; Maali et al., 2006; Abdul Rahman et al., 2010; Hassan and Harahap, 2010; Aribi and Gao, 2012 Ullah, 2013). Secondly, this study focuses on corporate governance mechanisms which contains board related variables to understand more completely how these factors jointly impact on the level of compliance and CSR disclosure. Thirdly, the impact of disclosure on firm value still remains inconclusive (Vogel 2005; Hassan et al., 2009; Al-Akra et al, 2010) and an open empirical question, particularly for Islamic banks. There is a little direct empirical evidence with regard to the relationship between disclosure and firm value in general and for Islamic banks in particular. Such inconclusiveness creates ground for further investigation such as CSR. While evidence proposes that proactive social accountability enhances firm value and AAOIFI has issued governance standards for Islamic banks focusing on enhancing CSR, there is an absence of academic research that investigates the prospective economic consequences and social disclosure for Islamic banks. As such, this study fills this gap in the literature by providing a direct analysis on the effect of CSR on firm value through alternative measures of firm value. This study focus on Islamic banks that provides a unique empirical setting to investigate the prospective economic consequences and social disclosure for Islamic banks i.e. the impacts of CSR on firm value. The findings generate incremental insights to managers who seek to enhance the firm value (FV) of Islamic banks.

The remainder of the paper is organize as follows. Section 2 discusses the relevant literature review and the hypothesis development, followed by the research methodology and data in Section 3 and empirical results in Section 4. Finally, Section 5 provides brief discussion and concluding remarks.

\section{Review of literature and hypotheses development}

Generally, various theories have been developed to explain the variation between entities in terms of their level of disclosure. While there is no general or comprehensive disclosure theory that can be applied, it is argued that several theories such as agency theory, stakeholder theory and signalling theory could be used in an integrated framework to provide an explanation for managerial incentives which affect CSR disclosure (Al-Htaybat, 2005). These theories can explain the disclosure phenomena as well as managers' incentives for disclosure. Alberti-Alhtaybat et al. (2012) argue that disclosure theories, such as agency theory and stakeholder theory, would be of 
great help in explaining a particular phenomenon by providing clear insights in the understanding of the CSR disclosure practices. Prior studies (Farook et al., 2011) argue that there is a consistency between agency theory and stakeholder theory, therefore, both theories can be considered as interrelated theories to explain the determinants of CSR disclosure practice in GCC Islamic Banks. In general, agency theory concentrates on the relationship between the principal and the agents who are given the authority to manage the principal's interests and make beneficial decisions. According to general stakeholder theory, society expects corporations to behave in a manner that is beneficial in terms of their social or economic role. Again, the influence of CSR disclosure on firm value can be understood based on agency and signaling theory. Signalling theory can be applied in the event of information asymmetry where outsiders usually do not have access to the internal information about the company, which is only available to the managers. According to signalling theory, a manager discloses information in order to reduce information asymmetry and to signal to outsiders that a firm is performing better than its peers (Álvarez et al., 2008). Signalling theory posits that investors rely on the information delivered by firms (Abhayawansa and Abeysekera, 2009), highlighting that the credibility of information is crucial in ensuring less information asymmetry (Hughes, 1986).

Corporate governance mechanisms can be considered as essential factors, illustrative of the decisions of corporate disclosure related to CSR from agency and stakeholder theory perspectives. Very limited research has been undertaken to examine the link between corporate governance mechanisms and the CSR disclosure practice of GCC Islamic banks. Most of the previous studies, which explore corporate governance as a factor behind the disclosure level, just focused on governance variables related to board-related variables (Taylor et al., 2010; Cong and Freedman, 2011; Elzahar and Hussainey, 2012; Bokpin, 2013; Alhazaimeh et al., 2014). A limited number of studies explore governance related to Shariah supervisory board (SSB) as a unique mechanism for Islamic banks (Abdul Rahman and Bukair, 2013; Farook et al., 2011). According to Rahman and Bukair (2015), it is expected that numerous factors could drive variances between Islamic banks and its CSR disclosure practices. Previous studies (Jo and Harjoto, 2011; Wan Amalina Wan Abdullah, 2009) provide robust evidence on the corporate governance mechanisms which influence on the CSR information disclosure among the financial and non-financial companies. Thus, in developing the research hypothesis, this study use corporate governance characteristics as a main explanatory variables and firm characteristics as a control variable in 
measuring the determinants of CSR disclosure practice in Islamic banks.

\subsection{Hypotheses for determinants of CSR}

\subsubsection{Board size, composition and meeting}

The board of directors consists of the total number of executive and non-executive directors on the board. In general, the size of the boards in a company, such as an Islamic bank, can improve their efficiency in handling and solving any presence issues, such as CSR-related issues. Empirical evidence in corporate governance suggests that the board size impacts the level of controlling, monitoring, and disclosure (Rahman and Bukair, 2015). However, Wang and Hussainey (2013) claimed that larger boards' effectiveness is negatively affected by the presence of problems regarding communication and coordination. In turn, some studies have indicated that larger boards incorporate a variety of expertise, which result in greater effectiveness in terms of the boards' monitoring role (Singh et al., 2004; Abdel Fattah, 2007). Based on agency and signalling theory, this study expects that larger board sizes will increase board-monitoring capabilities; as a result, this gives positive influences to disclosure practice in Islamic banks.

Besides board size, board composition also reflects how much the banks are linked to the outside world, as a result, they will be more aware on CSR issues and improve their CSR disclosure practice. Board composition is the proportion of outside directors (non-executive/independence) and inside directors (executive/non-independence) to the total number of directors appointed in the company (Al-Saidi and Al-Shammari, 2013). Board composition is seen as an important indicator of board independence. It is stated that directors' independence can strengthen the board by monitoring, advising, and counselling the top management (Anderson and Reeb., 2004) and protecting the investors' interests (Petra, 2005). In particular, the non-executive directors are perceived to bring a fresh and wider view to board discussion and decision making, such as CSR disclosure practice. Based on legitimacy theory, it is anticipated that larger composition of nonexecutive boards would improve the CSR disclosure practice in Islamic banks

Frequent board meetings are important, because they enable the directors to control the company effectively (Tuggle et al. 2010; Hossain, 2008). Active boards members will tend to signal their performance to potential employers (Hasan, 2011). Laksamana (2008) and Taha (2010) find that there is a positive association between board meetings and transparency of compensation disclosure. In accordance with signalling theory where frequent board meeting represents more 
proactive board, a positive association between board meetings and CSR disclosure is expected. Thus, based on above discussion the following hypothesis is formulated:

\section{Hypothesis 1: Board size, composition and meeting have positive effects on CSR disclosure.}

\subsubsection{Board gender composition and cross-holding directorship}

In recent years, board diversity has become a significant element of governance arrangement. Branco and Rodrigues (2008) contend that the theme of board diversity correctly matches into the structure of stakeholder theory. Prior studies reported that more women on board contributes to a greater disclosure and higher incidence of assurance reports accompanying such disclosures (Fernandez-Feijoo et al., 2012), stronger orientation towards corporate social reporting and a higher intensity of social performance (Sicilian, 1996) and positive association with corporate social reporting (Amran et al., 2014). Therefore, firms with a higher proportion of women directors do engage in more CSR disclosure practices and CSR activities, such as charitable activities (Haniffa and Hudaib, 2007). Based on stakeholder theory, we argue that a higher proportion of women directors on the board are expected to influence the CSR disclosure in Islamic banks.

Another potential determinants related to the board characteristics are cross-holding directorship sitting on more than one board. It has been suggested in the literature (Ahmed, 2013; Rahman \& Bukair, 2013; Haniffa, 1999) that cross-holding directorship will help in making information more transparent, as well as encourage the sharing of experience. However, the concentration of decision-making power may result in opportunistic behaviour by that individual cross-holding director (Khan, 2010) and make them less independent (Aguilera, 1998; Young et al., 2008). Again, it is argued that cross-holdings will encourage companies to be transparent because such directors will have better knowledge of the practices in companies on which they sit (Lewis, 2005). Based on agency theory, Islamic banks which have no cross holding director are expected to have effective performance and better CSR disclosure score. Thus, based on above discussion the following hypothesis is formulated:

\section{Hypothesis 2: Board gender composition and cross-holding directorship have positive effects on CSR disclosure.}

\subsubsection{CEO duality}

Role duality in a position exists when the CEO (chief executive officer) is also the chairman of the board. Agency theory predicts that role duality creates individual power for the CEO that would affect the effective control exercised by the board (Zahir, 2008). It has been suggested in the 
previous literature (Tuggle et al., 2010; Hashim and Devi, 2008; Ramdani and Witteloostuijn, 2010; Peng et al., 2007) that these two roles should be separated, mainly for reasons of independence. Although the separation of roles is suggested, some companies are not prepared to be absolutely categorical about dividing the roles (Rahman and Bukair, 2015). Based on agency theory, Islamic banks which are free CEO duality issue are expected to have better CSR disclosure score. Thus, the following hypothesis is formulated:

\section{Hypothesis 3: CEO duality has negative effect on CSR disclosure.}

\subsubsection{SSB size and cross-membership}

The Shariah Supervisory Board has social influence and authority in monitoring the Islamic banks' compliance with Shariah principles and provides the confidence to stakeholders about the legitimacy of the business transactions. However, the degree to which the SSB influences the level of CSR disclosure is depending on SSB characteristics, such as board size. Therefore, the SSB size is expected to have a positive impact on CSR disclosure (Farook et al., 2011). Empirical evidence suggests that SSB size can affect the level of disclosure (Akhtaruddin et al., 2009). Based on AAOIFI Governance Standard No. 1, the SSB members in Islamic banks is between three and five members. Agency theory predicts that larger boards incorporate a variety of expertise that results in more effectiveness in the monitoring role of the boards (Singh et al., 2004). With more members, the collective knowledge and experience of SSB will increase, leading to greater disclosure. Concerned with banking sector, and especially Islamic banks, Farag et al. (2014) find a positive significant association between the Shariah supervisory board (SSB) size and disclosure index.

Cross memberships of SSB members may also lead to higher disclosure of CSR information (Dahya, Lonie and Power, 1996). Farook et al. 2011, suggest that cross-directorships will increase transparency and accountability in financial reporting. SSB members with crossmemberships will be exposed to more discussions about the application of Islamic law in banking, in particular to CSR disclosure practice. Thus, based on above discussion the following hypothesis is formulated:

\section{Hypothesis 4: SSB size and cross-membership have positive effects on CSR disclosure.}

\subsubsection{Audit committee size and meeting}

Audit committee monitoring is not only about the financial reporting process; it extends to the 
reporting of non-financial information ( $\mathrm{Li}$ et al., 2012) such as, CSR information disclosure. Mangena and Pike (2005) suggest that larger audit committees give rise to more effective monitoring. Li et al. (2012) report a positive relationship between audit committee size and the quality of financial reporting, while Tauringana and Mangena (2009) find no statistically significant relationship between the level of disclosure and audit committee size. Based on agency theory, it is expected that larger audit committee size will increase board-monitoring capabilities (Rahman and Bukhair, 2015).

An active audit committee with high frequency of meetings will have enough time to discharge its duties. Prior research provides evidence on a positive relationship between audit committee meetings and subcategories of financial reporting (Kelton and Yang, 2008; Li et al., 2012). Amran et al. (2014) recommend that AC meetings should not be fewer than three meetings a year to enhance the companies sustainable reporting. Based on agency theory, frequent audit committee meeting may provide effective monitoring to Islamic banks activities and better CSR information in their annual report. Thus, based on above discussion the following hypothesis is formulated:

\section{Hypothesis 5: Audit committee size and meeting have positive effects on CSR disclosure.}

\subsubsection{Institutional ownership and foreign ownership}

Agency theory predicts that ownership structure affects the level of disclosure. In the literature, the relationship between institutional ownership and disclosure is mixed ranging from positive, negative and no association (Barako et al., 2006; Mangena and Pike, 2005; Schadewitz and Blevins, 1998; Haniffa and Cooke, 2002). Akhigbe and Martin (2006) found a positive association between disclosure and institutional ownership, based on the financial services industry. Hidalgo et al. (2011 p.490) state that "the results appear to corroborate the view that an increase in institutional investor shareholding has a negative effect on voluntary disclosure, supporting the hypothesis of entrenchment, whereas an excessive ownership by institutional investors may have adverse effects on strategic disclosure decisions".

Foreign owners are typically assumed to play a key role in supporting CSR reporting strategies (Ayuso and Argandona, 2007). Agency theory for additional information increase with the increase in ownership numbers. Soderstrom and Sun (2007) contend that the extent of foreign investor ownership is an important determinant of the demand for financial information. Sharma 
(2014) and Haniffa and Cooke (2005) find a positive association between foreign ownership and disclosures. Thus, based on above discussion the following hypothesis is formulated:

\section{Hypothesis 6: Institutional ownership and foreign ownership have positive effects on CSR disclosure.}

\subsection{Hypotheses for effect of CSR on firm value}

In the literature, the impact of CSR disclosure on firm value is limited and it is scarce in GCC Islamic banks. Rhodes and Soobaroyen (2010) argue that disclosure can curtail agency problems by decreasing information asymmetry, thus enhance firm value. Sheu et al. (2010) contend that the market only provides a higher valuation to those corporations that elect to disclose inclusive information. Anam et al. (2011), Dhaliwal et al. (2011), Gordon et al. (2010) and Garay et al. (2013) report that the extent of disclosure has a significant positive effect on the firm value. Further, Villiers (2013) examines the effect of a firm's governance measures on the relationship between CSR disclosure and firm value and reveals a stronger link between CSR disclosures and firm value in stronger governance countries. Alotaibi and Hussainey (2016) find a positive relationship between CSR disclosure quality and market capitalization of Saudi non-financial listed companies. However, the direction and magnitude of the relationship is associated with the type of disclosure (Hassan et al., 2009) and the proxy that used for firm value (Uyar and Kiliç, 2012). Alotaibi and Hussainey (2016) argued that both CSR disclosure quantity and quality have the same impact on firm value, but the significance of this impact depends on the proxy used in measuring the firm value. The influence of CSR disclosure on firm value (FV) can be understood based on agency, signalling, and economic theory. most of prior studies (Rhodes and Soobaroyen (2010) Al-Akra et al (2010); Sheu et al (2010) Gordon et al (2010); Anam et al (2011);Dhaliwal et al (2011); Garay et al (2013) and Alotaibi and Hussainey (2016) ) find a positive relationship between the level of disclosure and firm value. Therefore, the following hypothesis is formulated:

\section{Hypothesis 7: CSR disclosure has a positive effect on firm value}

\section{Research methodology and data}

\subsection{Sample and data}

The current study uses secondary data relating to CSR disclosure, its determinants, and consequences. The data is collected from annual reports, Bank Scopes, data stream databases and 
company web sites. The sample banks are selected based on a criteria of full-fledged Islamic banks or banks which are $100 \%$ comply with Shariah. According to Bankers database, there are 62 fullfledged licensed Islamic banks in GCC. For the sake of consistency in the research sample, Islamic banks' subsidiaries and banks that have not published an English version of the annual report are excluded. Accordingly, 23 banks are excluded, leaving the final sample of this study consists of 39 Islamic banks, which represents $63 \%$ of the population. The study is conducted from 2010 due to the latest Governance Standards Issued by the AAOIFI in 2010. So, the dataset is designed for 5 years (2010-2014) with 39 Islamic banks (195 observations), providing sufficient information of disclosure practices across Islamic banks operating in the GCC countries. The fiscal year of 20102014 chosen to ensure a reasonable access to bank, reports' and gives a clear picture of disclosure practice. The sample breakdown across countries is summarized in Table 1.

Table 1: Sample breakdown across countries

\begin{tabular}{|c|c|c|c|}
\hline No & Countries & Total Number of Islamic Banks & Sample Islamic Banks \\
\hline 1 & Bahrain & 27 & 15 \\
2 & Qatar & 9 & 6 \\
3 & Kuwait & 6 & 3 \\
4 & KSA & 6 & 4 \\
5 & Oman & 5 & 3 \\
6 & UAE & 9 & 8 \\
\cline { 2 - 3 } & TOTAL & $\mathbf{6 2}$ & $\mathbf{3 9}$ \\
\hline \multicolumn{2}{l}{} \\
\multicolumn{2}{l}{} \\
\cline { 2 - 3 }
\end{tabular}

\subsection{Research methods}

This study adopts quantitative research approach. Yearly financial reports of the sample Islamic banks are gather from the Bank Scope Database and their websites. Other data such as, charitable activities and social responsibility in the index and details of their data which are not available in the financial report are collected from the banks newsletter and website. To measure the CSR disclosure quantity in the study, the un-weighted content analysis method is employed to code and measure CSR disclosures over the annual reports, ensuring the validity and the reliability of the analysis. ${ }^{3}$ Therefore, ' 1 ' is given for each CSR disclosed in the annual report, and ' 0 ' if there are no CSR disclosure items disclosed in the annual report. A total of 11 dimensions of the CSR

\footnotetext{
${ }^{3}$ If the Cronbach's Alpha shows more than 70\%, it means the measurement is reliable (Aryani, 2015). Un-tabulated result shows that Cronbach's alpha is $0.815(>0.70)$, meaning the initial checklist and items used in the study have high reliability.
} 
disclosure index are developed based on governance standard No.7 issued by AAOIFI, which relate to CSR disclosure requirement for Islamic banks and could be either mandatory or voluntary disclosure. The main dimensions of the index consist of four main aspects, which cover the issues of social responsibility within organizations, social responsibility in its relationship with customers and clients, social responsibility in screening its investments, and social responsibility in its relationship with greater society. Appendix 1 presents the summary of the main and subdimensions in measuring CSR disclosure practices among the sample Islamic banks in the GCC that are used in this study. Again, to enhance the reliability of the instrument, the disclosure items are coded and checked twice to ensure it is free from any potential discrepancies (Taliyang and Jusop, 2011). The quantity of disclosure is measured through the calculation of a Corporate Social Responsibility Disclosure Index (CSRDI) score. As indicated before, the approach to scoring items is essentially dichotomous in that an item in the research instrument scores ' 1 ' if communicated and ' 0 ' if it is not (Haniffa and Cooke, 2002; Haniffa and Hudaib, 2007), and is additive and equally weighted to avoid potential scoring bias and scaling problems (Cooke, 1989). The method used in measuring the CSR disclosure level of the sample Islamic banks is as follows:

$$
\operatorname{CSRDI}(i, t)=\sum_{i=1}^{N} \operatorname{Score}(j)
$$

Where:

CSRDI = corporate social reporting index score for company $i$. and for the year $t$ $\mathrm{N}=$ number of items in the index

$\mathrm{j}=$ indicates each item included in the index

Thus, the value of the index, for each companies $i$ for the year $t$, is obtained as the sum of the scores assigned to each item in Score (j). It can be standardized as follows:

$$
\operatorname{CSRDI}(i, t)=\left(\frac{\sum_{i=1}^{N} \operatorname{Scor} e(j)}{N}\right) \times 100=\frac{\operatorname{Total} \operatorname{Score}(i, t)}{N} \times 100
$$

\subsection{Regression models}

To test hypotheses 1-6 empirically, the association between CSR disclosure levels with governance variables (board, SSB, audit committee, and ownership variables), a comprehensive regression model that consists of 6 board-related variables, 2 SSB-related variables, 2 audit committee related variables and 2-ownership variables has been developed. It also adds control variables consisting of 5 firms' characteristics variables and 2 country-specific variables. Accordingly, using 
the same procedure of Chan et al. (2012), the following OLS regression technique is applied:

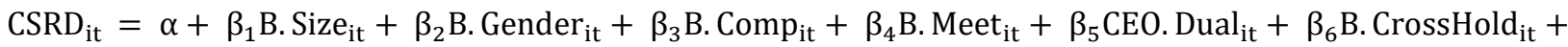

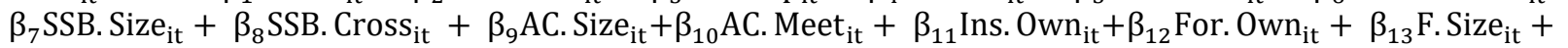

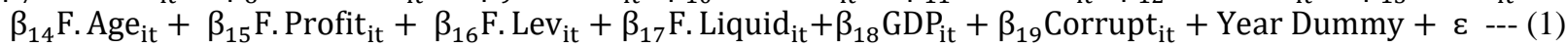

Where:

$\operatorname{CSRD}_{\text {it }}=$ is the total CSR disclosure score provided by CSR disclosure index, which measures the level of disclosure CSR in the sample Islamic banks $\boldsymbol{i}$ at year $\boldsymbol{t}$ or known as the dependent variable. Summary of CSR disclosure dimensions is set out in Appendix 1.

$\beta 1-\beta 12=$ independent variables. CG Variables consists of: B. Size (board size), B. Gender (board gender), B. Comp (board composition), B. Meet (board meeting), B. Dual (board duality), B. Cross Hold (board cross holding), SSB size, SSB cross membership, AC Size (audit committee size), AC Meet (audit committee meeting), Ins. Own (institutional ownership), and For. Own (foreign ownership). Variable definitions are set out in Appendix 2.

$\beta 13-\beta 19=$ control variables. Firms (in this study refers to Islamic banks) and country-specific variables consist of: F. Size (firm size), F. Age (firm age), F. Profit (firm profitability), F. Lev. (firm leverage), F. Liquid (firm liquidity), GDP (gross domestic product of the country) and Corrupt (the corruption index of the country). Firm and countryspecific characteristics variables of the sample Islamic banks have been collected from various databases such as DataStream, World Bank, Transparency index database and annual reports. Variable definitions are set out in Appendix 2.

Year dummy variables $=$ Year 2010, 2011, 2012, 2013, 2014 as a dummy variable.

Again, to test hypotheses 7 empirically, the relationship between the CSR disclosure levels and firm value, this study applies the following OLS regression:

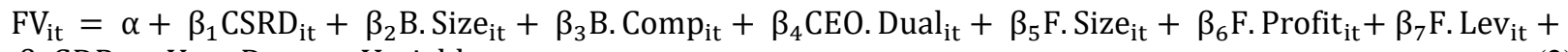
$\beta_{8} \mathrm{GDP}_{\text {it }}+$ Year Dummy Variable $+\varepsilon$

Where:

$\mathrm{FV}=$ is the firm value measured using MTBV (market-to-book ratio) or MC (market capitalisation) or TQ (Tobin's Q) as proxy for sample Islamic banks also known as dependent variable. Variable definitions are set out in Appendix 2 .

$\beta 1=$ Independent variables (CSRD score of the sample Islamic banks).

$\beta 2-\beta 8=$ Control variables (governance, firm and country specific variables).

Year dummy variables = Year 2010, 2011, 2012, 2013, 2014 as a dummy variable.

\section{Empirical results}

This study conducts the Kolmogorov-Smirnov test to ensure that the data are normally distributed. Based on the test, it finds that all data is normally distributed. Following Aryani (2015), heteroscedasticity test is also conducted and the un-tabulated result shows that all variables are more than 0.05 indicating no sign of heteroscedasticity problem. Again, to avoid multicollinearity among the independent variables that would affect the reliability of the estimates and may cause a 
wide inflation in the standard errors for the coefficient, Pearson correlation matrix is tested. Gujarati (2003) indicates that collinearity among the independent variables is acceptable if the correlation coefficient (r) is at maximum as 0.80 . The un-tabulated Pearson correlation matrix results shows that there is no multicollinearity problem in this study as the association among the variables are below 0.80. In addition, variance inflation factor (VIF) is calculated. This procedure is an additional step to ensure that explanatory variables are not extremely correlated. The rule that has been applied is correlation between independent variables is accepted if VIF is still smaller than 10 (Gujarati, 2003). The un-tabulated VIF results of this study are higher than 0.1 and less than 10, implying that the variables do not have a multicollinearity/autocorrelation problem.

\subsection{CSR disclosure in GCC countries}

Table 2 presents the cross-country analysis (Panel A) and cross-dimensional analysis (Panel B) of CSR disclosure of 195 observations of the GCC Islamic banks between 2010 and 2014 compliant with the AAOIFI's Governance Standard No. 7. Panel A shows an improvement of CSR disclosure practice among Omani and KSI banks than other GCC countries. There is no significant difference of CSR disclosure practice among the GCC Islamic banks after issuance of AAOIFI, No. 7, suggesting that the AAOIFI has no influence on the GCC Islamic banks. From the dimensional analysis in Panel B, it appears that the GCC Islamic banks tend to disclose employee-related information and Zakat in their annual report more than other CSR information. Overall, the result shows a low level of disclosure for CSR reporting for the sample Islamic banks. Again, the mean CSR disclosure of the sample Islamic banks is 39.92\%, which is far short of expectation. This implies that Islamic banks are not completely fulfilling their social role in accordance with the Islamic principles. Low level of CSR disclosure score indicates that Islamic bank managers are less accountable in performing their duties and expected to be more aware on CSR issues in future.

Table 2: Cross-country and cross-dimensional analysis of CSRD for GCC Islamic banks Panel A: Cross-country analysis of CSRD for GCC Islamic Banks (2010-2014)

\begin{tabular}{|c|c|c|c|c|c|c|c|c|c|c|}
\hline COUNTRY & $2010(\%)$ & Ranks & 2011(\%) & Ranks & $2012(\%)$ & Ranks & $2013(\%)$ & Ranks & $2014(\%)$ & Ranks \\
\hline 1) UAE & 51.1 & 2 & 43.2 & 3 & 37.5 & 3 & 45.5 & 2 & 43.2 & 3 \\
\hline 2) BAHRAIN & 45.5 & 4 & 34.6 & 5 & 30.9 & 5 & 41.2 & 3 & 35.2 & 4 \\
\hline 3) QATAR & 47.0 & 3 & 34.9 & 4 & 36.4 & 4 & 33.3 & 4 & 30.3 & 6 \\
\hline 4) KUWAIT & 54.6 & 1 & 45.5 & 2 & 45.5 & 1 & 45.5 & 2 & 33.3 & 5 \\
\hline 5) $\mathrm{KSA}$ & 43.2 & 5 & 50.0 & 1 & 38.6 & 2 & 45.5 & 2 & 52.3 & 2 \\
\hline 6) OMAN & 27.3 & 6 & 24.2 & 6 & 24.2 & 6 & 51.5 & 1 & 60.6 & 1 \\
\hline & \multicolumn{10}{|c|}{ Mean CSRD across 2010-2014: $\mathbf{3 9 . 9 2} \%$} \\
\hline \multicolumn{11}{|c|}{ Panel B: Cross-dimensional analysis of CSRD score and percentage for GCC Islamic banks (2010-2014) } \\
\hline Items & \multicolumn{2}{|c|}{2010} & \multicolumn{2}{|c|}{2011} & \multicolumn{2}{|c|}{2012} & \multicolumn{2}{|c|}{2013} & \multicolumn{2}{|c|}{2014} \\
\hline
\end{tabular}




\begin{tabular}{|c|c|c|c|c|c|c|c|c|c|c|}
\hline & Score & $\%$ & Score & $\%$ & Score & $\%$ & Score & $\%$ & Score & $\%$ \\
\hline 1) EY & 38 & 97.4 & 38 & 97.4 & 39 & 100 & 38 & 97.4 & 39 & 100 \\
\hline 2) $\mathrm{EV}$ & 8 & 20.5 & 1 & 2.5 & 5 & 12.8 & 14 & 35.9 & 4 & 10.2 \\
\hline 3) NSE & 5 & 12.8 & 14 & 35.9 & 13 & 33.3 & 18 & 46.1 & 23 & 58.9 \\
\hline 4) $\mathrm{CS}$ & 25 & 64.1 & 10 & 25.6 & 6 & 15.3 & 11 & 28.2 & 5 & 12.8 \\
\hline 5) LP & 4 & 10.2 & 1 & 2.5 & 1 & 2.5 & 1 & 2.5 & 1 & 2.5 \\
\hline 6) Qard & 16 & 41 & 20 & 51.2 & 19 & 48.7 & 19 & 48.7 & 21 & 53.8 \\
\hline 7) $\mathrm{SME}$ & 20 & 51.2 & 19 & 48.7 & 20 & 51.2 & 22 & 56.4 & 22 & 56.4 \\
\hline 8) S.Client & 13 & 33.3 & 4 & 10.2 & 0 & $\mathbf{0}$ & 1 & 2.5 & 3 & 7.6 \\
\hline 9) Zakat & 31 & 79.4 & 31 & 79.4 & 34 & 87.1 & 38 & 97.4 & 37 & 94.8 \\
\hline 10) Charity & 32 & 82 & 21 & 53.8 & 10 & 25.6 & 19 & 48.7 & 11 & 28.2 \\
\hline 11) Waqf & 5 & 12.8 & 4 & 10.2 & 1 & 2.5 & 1 & 2.5 & 4 & 10.2 \\
\hline \multicolumn{11}{|c|}{$\begin{array}{l}\text { 1. Employee welfare (EY) 2. Policy for social, development and environment based investment quotas (EV) 3. Earning and expenditure prohibited by } \\
\text { Shariah (NSE) 4. Par excellence customer services (CS) 5. Policy for dealing with clients for late repayment and insolvent clients and avoiding onerous } \\
\text { terms (LP) 6. Qard-Hassan (benevolent loan) (Qard) 7. Micro and small business and social savings, investments and development (SME) 8. Policy for } \\
\text { screening clients for compliance with Islamic principles (S.Client) 9. Zakat (Zakat) 10. Charitable activities (Charity) 11. Endowment management } \\
\text { (Waqf). Score (CSR disclosure score of sample Islamic banks) \% (Percentage of CSR disclosure score of sample Islamic banks) }\end{array}$} \\
\hline
\end{tabular}

\subsection{Determinants of CSR disclosure and its effect on firm value in GCC countries}

\subsubsection{Descriptive Statistics}

Table 3 provides the descriptive statistics in Panel A for the variables used in equation 1 to examine CSR disclosure determinants, while descriptive statistics in Panel B for the variables used in equation 2 to examine the effect of CSR disclosure on firm value. In Panel A, the mean value of CSR disclosure quantity (CSRD) is 0.3992 , with a minimum and maximum of value of 0.09 and 0.73, respectively. Average board size of the sample Islamic banks is 9, with maximum 16 and minimum 4 members. Again, SSB average size is 4 and minimum 3, maximum 6 members. On average, $82 \%$ directors are male and $18 \%$ female, while $34 \%$ directors are independent. Board meeting has a mean value of 6.45, with minimum 4 and maximum 11 meetings in a year. $18 \%$ firms have CEO duality and $85 \%$ directors have cross directorships. Again, SSB average cross holding is $80 \%$. Mean value of audit committee size is 4, with minimum 2 and maximum 7 members. Audit committee meeting has a mean value of 5.25, with minimum 2 and maximum 7 meetings in a year. Mean values of institutional and foreign ownerships are 19\% and 18\%, respectively. Further, in Panel B, the average natural logarithm of market value of market to book value of equity ratio (MTBV) is 1.5960, while market capitalization (MC) and TQ (Tobin's Q) are, respectively 6.3477 and 0.81 .

Table 3: Descriptive Statistics of Variables

\begin{tabular}{|l|c|c|c|c|}
\hline \multicolumn{5}{|c|}{ Panel A: Equation 1 Variables 2010-2014 (N=195) } \\
\hline \multicolumn{1}{|c|}{ Variables } & Mean & Std. Deviation & Minimum & Maximum \\
\hline CSRD & 0.3992 & 0.13026 & 0.09 & 0.73 \\
\hline
\end{tabular}




\begin{tabular}{|c|c|c|c|c|}
\hline B.SIZE & 9.1538 & 2.24227 & 4.00 & 16.00 \\
\hline B.GENDER & 0.8205 & 0.38475 & 0.00 & 1.00 \\
\hline B.COMP & 0.3386 & 0.12557 & 0.10 & 0.75 \\
\hline B.MEET & 6.4564 & 1.16738 & 4.00 & 11.00 \\
\hline CEO.DUAL & 0.1795 & 0.38475 & 0.00 & 1.00 \\
\hline B.Cross HOLD & 0.8462 & 0.36173 & 0.00 & 1.00 \\
\hline SSB SIZE & 4.0769 & 1.02506 & 3.00 & 6.00 \\
\hline SSB CROSS & 0.7949 & 0.40483 & 0.00 & 1.00 \\
\hline AC SIZE & 4.1282 & 1.04486 & 2.00 & 7.00 \\
\hline AC MEET & 5.2564 & 0.90582 & 2.00 & 7.00 \\
\hline INS. OWN & 0.1926 & 0.06671 & 0.11 & 0.40 \\
\hline FOR.OWN & 0.1852 & 0.04811 & 0.11 & 0.33 \\
\hline F.SIZE & 3.5987 & 1.05947 & 1.10 & 5.84 \\
\hline F.AGE & 17.8000 & 14.61379 & 1.00 & 57.00 \\
\hline F.PROFIT & 8.2287 & 14.12631 & -127.15 & 24.19 \\
\hline F.LEV & 110.4239 & 108.22184 & 0.04 & 771.16 \\
\hline F.LIQUID & 48.8651 & 22.18020 & 0.36 & 84.44 \\
\hline $\begin{array}{l}\text { C.GDP } \\
\text { C.GP }\end{array}$ & 10.8787 & 0.48287 & 10.32 & 11.72 \\
\hline C.CORRUPT & 5.5662 & 1.03724 & 4.30 & 7.70 \\
\hline \multicolumn{5}{|c|}{ Panel B: Equation 2 Variables 2010-2014 $(\mathrm{N}=195)$} \\
\hline Variables & Mean & Std. Deviation & Minimum & Maximum \\
\hline MTBV & 1.5960 & 1.11883 & 0.30 & 6.79 \\
\hline $\mathrm{MC}$ & 6.3477 & 0.94080 & 3.92 & 8.17 \\
\hline TQ & 0.8102 & 0.14803 & 0.00 & 0.93 \\
\hline CSRD & 0.3992 & 0.13026 & 0.09 & 0.73 \\
\hline B.SIZE & 9.1538 & 2.24227 & 4.00 & 16.00 \\
\hline B.COMP & 0.3386 & 0.12557 & 0.10 & 0.75 \\
\hline CEO.DUAL & 0.1795 & 0.38475 & 0.00 & 1.00 \\
\hline F.SIZE & 3.5987 & 1.05947 & 1.10 & 5.84 \\
\hline F.PROFIT & 8.2287 & 14.12631 & -127.15 & 24.19 \\
\hline F.LEV & 110.4239 & 108.22184 & 0.04 & 771.16 \\
\hline GDP & 10.8787 & 0.48287 & 10.32 & 11.72 \\
\hline
\end{tabular}

\subsubsection{Empirical Analysis for Determinants of CSR Disclosure}

Table 4 presents empirical analysis of CSR disclosure determinants of Islamic banks in the GCC.

Board size has a coefficient of 0.174 , showing positive significant impact on the levels of CSR disclosure at 5\% level of significance. Therefore, $\mathrm{H} 1$ is accepted. This indicates that increased board membership enhances CSR disclosure, consistent with the studies of Singh et al. (2004), Cheng and Courtenay (2006), Abdel-Fattah et al. (2007) and Laksamana (2008). The benefit of 
having a larger board is that it can increase company's value, because they provide a firm with members from different fields of expertise (Khan 2010). Islamic banks with a higher board size do engage to a greater extent in CSR disclosure practices and CSR activities. Again, as expected, a negative significant relation is found between CEO duality and CSR disclosure practice among GCC Islamic banks at 5\% significance level. Therefore, $\mathrm{H} 3$ is also rejected. This is not consistent to agency theory as CEO duality is seen as detrimental to disclosure because of the 'dominant personality' phenomenon. This result is consistent with prior studies (Tuggle et al., 2010; Hashim and Devi, 2008; Ramdani and Witteloostuijn, 2010; Peng et al., 2007), suggesting these two roles should be separated in enhancing the monitoring quality and disclosure practice. Although the separation of roles is suggested, some companies are not prepared to be categorical about dividing the roles (Rahman and Bukair 2015). Thus, the assumptions that separation of chair and CEO roles will enhance the monitoring quality and improve benefits from not withholding information such as CSR reporting can be rejected. Further, the analysis also shows that there is a significantly negative relationship between audit committee size and the CSR disclosure practice among GCC Islamic banks at $5 \%$ level of significance, which is contrary to expectation and contradictory to the findings of Li et al. (2012) showing positive relationship and Tauringana and Mangena (2009) showing no statistically significant relationship. Therefore, H5 is rejected. This is may be due to the lack of audit committee function to influence the board/management.

Table 4 results also show that there is no association between CSR disclosure and other governance variables, which is consistent with the argument by Ho and Wong (2001) that corporate governance mechanisms may be substitutive and may not affect disclosure scores. As for control variables, only country GDP appears to have positive effect on CSR disclosure at 5\% level of significance and others show no significant relationship. It is in line with Olken \& Pande (2012) who find that there is a positive association between GDP and the level of disclosure. Regarding year dummy variables, only 2010 shows positive effect on CSR disclosure. Overall, the above findings have practical implications for the GCC Islamic banks to improve their governance mechanisms for ensuring enhanced CSR disclosure. The result shows that Islamic banks may have to increase their board size and abandon CEO duality for robust increase in CSR disclosure and meet stakeholders' expectations.

Table 4: Regression Results on Determinants of CSR Disclosure

Variables

Sign

Standardize Coefficients $\mathbf{t}$

Sig. Collinearity Statistics 


\begin{tabular}{|c|c|c|c|c|c|c|c|}
\hline & Expect & Actual & Beta & & & Tolerance & VIF \\
\hline Constant & & & 0 & -1.784 & $0.076^{*}$ & 0 & 0 \\
\hline B.SIZE & + & + & +0.176 & 2.049 & $0.042 * *$ & 0.584 & 1.711 \\
\hline B.GENDER & + & + & +0.129 & 1.571 & 0.118 & 0.637 & 1.570 \\
\hline B.COMP & + & - & -0.032 & -0.368 & 0.713 & 0.574 & 1.742 \\
\hline B.MEET & + & - & -0.014 & -0.131 & 0.896 & 0.401 & 2.496 \\
\hline CEO.DUAL & - & - & -0.204 & -2.021 & $0.045 * *$ & 0.424 & 2.356 \\
\hline B.CROSS.HOLD & + & - & -0.010 & -0.124 & 0.902 & 0.709 & 1.411 \\
\hline SSB SIZE & + & + & +0.172 & 1.364 & 0.174 & 0.272 & 3.681 \\
\hline SSB CROSS & + & - & -0.010 & -0.103 & 0.918 & 0.439 & 2.279 \\
\hline AC SIZE & + & - & -0.194 & -2.100 & 0.037 ** & 0.507 & 1.972 \\
\hline AC MEET & + & + & +0.127 & 1.449 & 0.149 & 0.562 & 1.780 \\
\hline INS. OWN & + & + & +0.000 & 0.002 & 0.999 & 0.797 & 1.255 \\
\hline FOR.OWN & + & - & -0.025 & -0.337 & 0.736 & 0.808 & 1.237 \\
\hline F.SIZE & + & - & -0.073 & -0.662 & 0.509 & 0.352 & 2.838 \\
\hline F.AGE & + & + & +0.034 & 0.318 & 0.751 & 0.375 & 2.668 \\
\hline F.LIQUID & + & + & +0.149 & 1.498 & 0.136 & 0.438 & 2.285 \\
\hline F.PROFIT & + & - & -0.015 & -0.190 & 0.850 & 0.694 & 1.442 \\
\hline F.LEV & - & + & +0.119 & 1.423 & 0.156 & 0.621 & 1.611 \\
\hline GDP & + & + & +0.268 & 2.216 & $0.028 * *$ & 0.294 & 3.396 \\
\hline CORRUPT & - & + & +0.018 & 0.172 & 0.864 & 0.400 & 2.502 \\
\hline Y2010 & & & +0.277 & 3.144 & $0.002 * *$ & 0.555 & 1.803 \\
\hline Y2012 & & & -0.113 & -1.345 & 0.180 & 0.606 & 1.651 \\
\hline Y2013 & & & +0.126 & 1.427 & 0.155 & 0.550 & 1.820 \\
\hline Y2014 & & & +0.006 & 0.070 & 0.944 & 0.560 & 1.786 \\
\hline Adjusted R Square & \multicolumn{7}{|c|}{0.164} \\
\hline Std.Error & \multicolumn{7}{|c|}{0.11910} \\
\hline Sig. & \multicolumn{7}{|c|}{0.000} \\
\hline Observation & \multicolumn{7}{|c|}{195} \\
\hline $\begin{array}{l}\text { All variables are defined } \\
\text { B.Dual (board duality), } \\
\text { board cross membership } \\
\text { Own (Managerial owner } \\
\text { equity), GDP (gross dom } \\
*, * *, * * * \text { indicates sign }\end{array}$ & $\begin{array}{l}\text { lows: B.S } \\
\text { sHold (b } \\
\text { Size (aud } \\
\text { F.Size (fi } \\
\text { product) } \\
\text { ce at } 10 \%\end{array}$ & $\begin{array}{l}\text { board size } \\
\text { cross hol } \\
\text { ommittee } \\
\text { ize), F.A } \\
\text { Corupt (1 } \\
\text {, \& } 1 \% \text {, }\end{array}$ & $\begin{array}{l}\text { nder (board } \\
\text { SB Size (S } \\
\text { C Meet (au } \\
\text { age), F.Pr } \\
\text { orruption) } \\
\text { vely. }\end{array}$ & $\begin{array}{l}\text { der), B.Bom } \\
\text { ah superviso } \\
\text { ommittee m } \\
\text { (return on as }\end{array}$ & $\begin{array}{l}\text { (board com } \\
\text { board size } \\
\text { ting), InsO } \\
\text { t), F.Lev (f }\end{array}$ & $\begin{array}{l}\text { n), B.Meet (1 } \\
\text { Cross (Shar } \\
\text { stitutional or } \\
\text { verage), F.Li }\end{array}$ & $\begin{array}{l}\text { meeting), } \\
\text { upervisory } \\
\text { hip), Man } \\
\text { (return on }\end{array}$ \\
\hline
\end{tabular}

\subsubsection{Empirical Analysis for Effect of CSR Disclosure on Firm Value}

Table 5 presents the results of the regression analyses of CSR disclosure consequences for Islamic banks in GCC countries. The results show a significant negative relationship between CSR disclosure and firm value proxied by MC, rather than MTBV and TQ, at 10\% significant level, therefor $\mathrm{H} 7$ is not supported. This finding is consistent with prior research, such as Hassan et al. (2009), Elliott et al. (2014), who show that CSR disclosure is negatively associated with firm value 
because of competitive disadvantage with rivals or making more noise to the investors. Nevertheless, it is contrary to Klein et al. (2005), Sheu et al. (2010), Gordon et al. (2010) and Anam et al. (2011) who point out that social disclosure has an impact on firm value based on signalling theory. As argued by Rhodes and Soobaroyen (2010) that disclosure cannot curtail agency problems by decreasing information asymmetry and enhance the firm value. However, it can be said the direction and magnitude of the relationship is associated with the type of disclosure (Hassan et al., 2009) and the proxy that is used for firm value (Uyar and Kiliç, 2012; Alotaibi and Hussainey, 2016). Thus, there is a conflicting relationship of determining the relationship between CSR disclosure and firm value. In addition, there is no agreement in the literature about an ideal measure for firm value (Mangena et al., 2012; Albassam, 2014).

With respect to governance variables, the results indicate that better governance leads to a higher firm value. Both board size and board composition have significant positive effect on firm value, respectively with MTBV and MC. These findings are consistent with existing literature (Giraldez and Hurtado, 2014; Colombo and Baglioni, 2008). Again, contrary to expectation, CEO duality has shown a positive significant effect on firm value as proxied by MTBV and MC. This finding can be explained by signaling theory, as CEO duality seems to be perceived by stakeholders as a signal of effective control and leadership. This finding is in line with a prior studies such as Peng et al. (2007) and Yang and Zhao (2014). Further, regarding control variables, firm profitability appear to have significant positive association with firm value proxy MTBV, consistent with Setia-Atmaja (2009), while GDP also reveals significant positive association with both MTBV and MC. On the other hand, firm size shows a negative significant relationship with MTBV, which is opposite to the findings of Ezat (2010) and Hassan et al. (2009). Finally, it is noted that Tobin's q (TQ) as a proxy in measuring firm value does not demonstrate any significant relationship with any variables. Dybvig and Warachka (2015) argue that Tobin's Q does not measure firm performance, rather firm value with respect to efficiency measure and cost discipline.

Table 5: Regression Results for the Effects of CSR Disclosure on Firm Value

\begin{tabular}{|l|c|c|c|c|c|c|c|c|c|c|}
\hline \multirow{2}{*}{ Variables } & \multirow{2}{*}{$\begin{array}{l}\text { Exp. } \\
\text { Sign }\end{array}$} & \multicolumn{4}{|c|}{ MTBV } & \multicolumn{3}{c|}{ MC } & \multicolumn{3}{c|}{ Tobin-Q } \\
\hline Constant & & $\mathbf{t}$ & Sig. & Coef. & $\mathbf{t}$ & Sig. & Coef. & t & Sig. \\
\hline CSRD & + & -1.482 & 0.140 & 0 & -5.248 & $0.000^{* * *}$ & 0 & 1.783 & $0.076 *$ \\
\hline B.SIZE & + & 0.036 & 0.461 & 0.645 & -0.096 & -1.705 & $\mathbf{0 . 0 9 0} *$ & 0.052 & 0.643 & 0.521 \\
\hline B.COMP & + & 0.006 & 0.077 & 0.938 & 0.088 & 1.712 & $\mathbf{0 . 0 8 9} *$ & -0.020 & -0.274 & 0.785 \\
\hline CEO.DUAL & - & 0.238 & 3.150 & $\mathbf{0 . 0 0 2} * * *$ & 0.143 & 2.651 & $\mathbf{0 . 0 0 9} * * *$ & 0.120 & 1.549 & 0.123 \\
\hline
\end{tabular}




\begin{tabular}{|c|c|c|c|c|c|c|c|c|c|c|}
\hline F.SIZE & + & -0.192 & -2.166 & $0.032 * *$ & -0.030 & -0.477 & 0.634 & 0.079 & 0.865 & 0.388 \\
\hline F.PROFIT & + & 0.111 & 1.400 & 0.163 & 0.202 & 3.560 & $0.000 * * *$ & 0.083 & 1.016 & 0.311 \\
\hline F.LEV & - & 0.073 & 0.907 & 0.366 & 0.020 & 0.350 & 0.727 & 0.083 & 0.998 & 0.319 \\
\hline GDP & + & 0.178 & 1.906 & 0.058* & 0.647 & 9.665 & $0.000 * * *$ & 0.034 & 0.352 & 0.725 \\
\hline Y2011 & & -0.077 & -0.841 & 0.401 & -0.097 & -1.474 & 0.142 & 0.125 & 1.324 & 0.187 \\
\hline Y2012 & & -0.093 & -0.990 & 0.324 & -0.137 & -2.052 & $0.042 * *$ & 0.127 & 1.323 & 0.188 \\
\hline Y2013 & & -0.028 & -0.316 & 0.752 & -0.060 & -0.938 & 0.350 & 0.141 & 1.518 & 0.131 \\
\hline Y2014 & & -0.007 & -0.071 & 0.943 & -0.079 & -1.186 & 0.237 & 0.180 & 1.892 & $0.060 *$ \\
\hline Adjusted R Square & \multicolumn{4}{|c|}{0.072} & \multicolumn{3}{|c|}{0.524} & \multicolumn{3}{|c|}{0.014} \\
\hline Std.Error & \multicolumn{4}{|c|}{1.077} & \multicolumn{3}{|c|}{0.649} & \multicolumn{3}{|c|}{0.14696} \\
\hline Sig. & \multicolumn{4}{|c|}{0.011} & \multicolumn{3}{|c|}{0.00} & \multicolumn{3}{|c|}{0.261} \\
\hline Observation & \multicolumn{4}{|c|}{195} & \multicolumn{3}{|c|}{195} & \multicolumn{3}{|c|}{195} \\
\hline
\end{tabular}

\section{Discussion and concluding remarks}

The aim of this research is to examine the level of CSR disclosure, its determinants and consequences among the 39 sample Islamic banks in the GCC countries with a total of 195 observations for the period 2010 to 2014. Developing a comprehensive CSR disclosure index based on previous literature and AAOIFI Governance Standard No. 7 guidelines, it highlights the extent of effectiveness of wide-ranging corporate governance variables (board, SSB, audit committee and ownership related) in determining CSR disclosure and its impact on firm value. The study finds that the level of CSR disclosure among the sample GCC Islamic banks is relatively low, indicating that the issuance of AAOIFI guidelines on CSR disclosure could not improve the CSR disclosure practice among Islamic banks in GCC countries. The CSR disclosures are still relatively low as compared to studies conducted before the issuance of AAOIFI guidelines. Several studies indicate that Islamic banks are not completely fulfilling their social role in accordance with the prescriptions of Islam. Based on the finding, it appears that Islamic banks are mainly focused on economic incentives more so than religious and social norms. It is thus, suggested that Islamic banks should enhance their CSR disclosure practice to ensure that its operations and activities are in line with Islamic banking principles. Therefore, policymakers should be more aggressive in encouraging Islamic banks to adopt AAOIFI Governance Standard No. 7 as a benchmark for CSR disclosure.

In term of the effect of corporate governance characteristics on CSR disclosure, this study 
reports that a larger size of board of directors do engage in greater extent of CSR disclosure practices and CSR activities. It also finds that CEO duality and audit committee size are inversely affecting CSR disclosure, which is indicative of disruption to voluntary disclosure. Other CG characteristics variables also have no significant relationship with the level of total CSR disclosure among Islamic banks. It can be argued that corporate governance mechanisms are substitutive and may not affect voluntary disclosures.

In addition, this study also analyses the impact of CSR disclosure on firm value based on three different proxies, namely market-to-book value (MTBV), market capitalization (MC) and Tobin's Q (TQ). The finding confirms a significant negative association between CSR disclosure and firm value (MC). This negative link between disclosure and firm value can be explained from signalling theory, rather than agency theory, perspective. Extra information could have a negative effect on firm value in the sense that the excessive CSR information disclosed may cause extra noise to the investors, which affects negatively on their valuation of the firm. Further, the negative effect on firm value could be driven by the content of the CSR information disclosed and how investors perceive it. There is a possibility that CSR information itself raises concerns about firm performance, which leads investors to lower their valuation. While CSR information could offer positive news to the stakeholders, they might misinterpret the practice that competitor firms would benefit from this excessive information. Nevertheless, this result does not support the idea that Islamic banks can use corporate disclosure to differentiate themselves and enhance their competitive advantage through increasing firm value. Again, the results reveals that the board size, board composition and CEO duality have significant positive effect on firm value, suggesting influence of dominant personality or leadership in GCC countries.

This study contributes to existing CSR reporting literature as being the first to examine the determinants of CSR disclosure in GCC Islamic banks for the year 2010-2014 using comprehensive corporate governance variables. Moreover, it provides a valuable contribution to research as it extends the understanding of how the CSR disclosure affects the firm value of GCC Islamic banks. The findings of the study have important implications for investors, managers, regulatory bodies, policy makers and Islamic banks. In an asymmetric information environment, corporate governance mechanisms are not yet as effective as expected for improving CSR disclosure. Despite Islamic banks are expected to fulfil their inherent character as an 'Islamic' bank and distinguish them from non-Islamic banks, the financial incentive is not evident because 
of negative performance effect of CSR disclosure.

However, managers who engage in good practices of information disclosure recommended continuing doing so. For those who refrain themselves from providing information to the stakeholders, the results call for more CSR transparency if they want their bank being more valuable on the eye of their stakeholders. Since there are many annual reports and websites of GCC Islamic banks having no disclosure of CSR information, the regulatory bodies and policy makers may identify a minimum benchmark for CSR disclosure that is published by each bank either in their annual reports or website. Further, regulatory bodies such as AAOIFI should be more proactive to guide Islamic banks toward the best practices of disclosures. They play a motivating role in this area of information disclosure. AAOIFI are also expected to have a strong collaboration with regulatory bodies in GCC countries to enhance CSR disclosure practice among Islamic banks. Thus, the findings of this study have important message for GCC Islamic banks, who may need to know that more CSR disclosure might have a significant impact on their firm value. They should be more aware of CSR disclosure issues, rather than focusing only on profit maximising objectives.

There are several limitations inherent in this study. Firstly, the relatively small sample size of 39 GCC Islamic banks (from 2010-2014) may limit the application of the findings to other IFIs such as Takaful and the Islamic Unit Trust Company. This is a common limitation of labourintensive type of studies using manual content analysis and manual data collection from annual reports. Further study may be conducted using a large sample of data over a longer time. Through exploring CSR disclosure using a time series data, future research can contribute more clear information regarding to CSR disclosure trends and practice among GCC Islamic banks. Secondly, this study only focuses on some governance variables (board-related, SSB-related variables, audit committee variables and ownership variables), therefore future study can add more governance variables which may provide better result. Thirdly, the study is also limited to discuss the AAOIFI Governance Standards No. 7, 2010 compliance among GCC Islamic banks. Further study may be conducted in measuring the level of compliance with other AAOIFI governance standards or national standards. Finally, other studies could explore other measures of firm value such as scale efficiency measures or examine the non-economic consequences of CSR disclosure and firm value, such as the image and reputation of the banks. 


\section{Reference:}

e.g. Capizzi, M.T. and Ferguson, R. (2005), "Loyalty trends for the twenty-first century", Journal of Consumer Marketing, Vol. 22 No. 2, pp. 72-80.

AAOIFI. (2010), corporate social responsibility conduct and disclosure for Islamic financial Institutions (Governance standard No.7). AAOIFI, Bahrain

Abdul Rahman, A. and Bukair, A. (2013), "The influence of the Shariah Supervision Board on corporate social responsibility disclosure by Islamic Banks of Gulf Co-Operation Council Countries", Asian Journal of Business and Accounting, Vol. 6, No. 2, pp. 65-105.

Abdul Rahman, A. Hashim, A. and Abu Bakar, F. (2010), "Corporate social reporting: A Preliminary Study of Bank Islam Malaysia Berhad (BIMB). Issues in Social and Environmental Accounting, 4 (1), 18-39

Abhayawansa, S. and Abeysekera, I. (2009). Intellectual capital disclosure from sell-siden analyst perspective. Journal of Intellectual Capital, 10 (2), 294-306

Abraham, S. and Cox, P. (2007). Analysing the determinants of narrative risk information in UK FTSE 100 Annual reports. The British Accounting Review, 39 (3), 227-248

Akhigbe and Martin (2006). Valuation impact of Sarbanes-Oxley: Evidence from disclosure andgovernance within the financial services industry. Journal of Banking \& Finance, 30, 9891006

Akhtaruddin, M. Hossain, M. Hossain, M. and Yao, L. (2009). Corporate Governance and Voluntary Disclosure in Corporate Annual Reports of Malaysian listed firms. Journal of Applied Management Accounting Research, 7 (1), 1-20

Al-Akra, M. Eddie, I. and Ali, M. (2010). The association between privatisation and voluntary 
Disclosure: Evidence from Jordan. Accounting and Business Research, 40 (1), 1-44

Alberti-Alhtaybat, L. Von, Hutaibat, K., \& Al-Htaybat, K. (2012). Mapping corporate disclosure theories. Journal of Financial Reporting and Accounting, 10(1), 73-94.

Al-hazaimeh, A. Palaniappan, R. and Almsafir, M. (2014). The Impact of Corporate Governance And Ownership Structure on Voluntary Disclosure in Annual Reports among Listed Jordanian Companies. Procedia Social and Behavioural Sciences, 129 (May), 341-348

Al-Mubarak, T., \& Osmani, N. M. (2010). Applications of Maqasid al-Shari'ah and Maslahah in Islamic Banking. In International Seminar on Islamic Finance.

Alotaibi, K. and Hussainey, K. (2016). The determinants of CSR disclosure quantity and quality: Evidence from non-financial listed firms in Saudi Arabia. International Journal of Disclosure and Governance, Forthcoming.

Al-Saidi, M., \& Al-Shammari, B. (2013). Board composition and bank performance in Kuwait: an empirical study. Managerial Auditing Journal, 28(6), 472-494.

Alvarez, I. Sanchez, I. and Dominguez, L. (2008). Voluntary and compulsory information Disclosed Online: The effect of industry concentration and other explanatory factors. Online Information Review, 32 (5), 596-622

Amin, H., Rahman, A. R. A., Jr, S. L. S., \& Hwa, A. M. C. (2011). Determinants of customers' intention to use Islamic personal financing: The case of Malaysian Islamic banks. Journal of Islamic Accounting and Business Research.

Amran, A., Lee, S. P., \& Devi, S. S. (2014). The Influence of Governance Structure and Strategic Corporate Social Responsibility Toward Sustainability Reporting Quality. Business Strategy and the Environment, 23(4), 217-235. 
Anam, O. Fatima, A. and Majdi, A. (2011). Effects of intellectual capital information disclosed In Annual reports on market capitalization: evidence from Bursa Malaysia. Journal of Human Resource Costing and Accounting, 15 (2), 85-101

Anderson, R. and Reeb, D. (2004). Board composition: balancing family influence in SandP 500 Firms. Administrative Sciences Quarterly, 49, 209-237

Aribi, Z. A., \& Gao, S. S. (2010). Corporate social responsibility disclosure: a comparison between Islamic and conventional financial institutions.

Aribi, Z. A., \& Gao, S. S. (2012). Narrative disclosure of corporate social responsibility in Islamic financial institutions. Managerial Auditing Journal, 27(2)

Aryani, D. N. (2015). The Determinants and Value Relevance Of Risk Disclosure In The Indonesian Banking Sector. University of Gloucestershire,UK.

Barako, G. Hancock, P. and Izan, H. (2006). Factors influencing voluntary corporate disclosure By Kenyan companies. Corporate Governance: An International Review, 14 (2), 107-125

Bhatti, M. and Bhatti, I. (2009). Development in legal issues of corporate governance in Islamic Finance. Journal of Economic and Administrative Sciences, 25, 67-91

Bokpin, G. (2013). Ownership structure, corporate governance and bank efficiency: an Empirical Analysis of panel data from the banking industry in Ghana. Corporate Governance: The International Journal of business in society, 13 (3), $274-287$

Branco, M. and Rodrigues, L. (2006). Communication of corporate social responsibility by Portuguese banks: A legitimacy theory perspective. Corporate Communications: An International Journal, 11 (3), 232 - 248

Chan, L., Chen, T.-Y., Janakiraman, S., \& Radhakrishnan, S. (2012). Reexamining the 
Relationship Between Audit and Nonaudit Fees: Dealing With Weak Instruments in Two-Stage Least Squares Estimation. Journal of Accounting, Auditing \& Finance,

Cheng, C. and Courtenay, S. (2006). Board composition, regulatory regime and voluntary Disclosure. The International Journal of Accounting, 41, 262-289

Cong, Y. and Freedman, M. (2011). Martin Freedman Corporate governance and Environmental Performance and disclosures incorporating. Advances in International Accounting, 27, 223-232

Cooke, E. (1989). Disclosure in the Corporate Annual Reports of Swedish Companies. Accounting and Business Research, 19 (74), 113-24

Dahya, J. Lonie, A. and Power, M. (1996). The case for separating the roles of chairman and CEO: An analysis of stock market and accounting data. Corporate Governance: An International Review, $4(2), 52-68$

Dhaliwal, D. Li, Z. Tsang, A. and Yang, Y. (2011). Voluntary nonfinancial disclosure and the cost Of equity capital: The initiation of corporate social responsibility reporting. The Accounting Review, 86, 59-100

"El-Gamal, M. A. (2005) Limits and Dangers of Shariah Arbitrage, In: Ali, N. (2005) Islamic ElGamal, M. A. (2005) Limits and Dangers of Shariah Arbitrage, In: Ali, N. (2005) Islamic Finance: Current Legal and Regulatory Issues, Cambridge: Islamic Finance Project Islamic Legal Studies Program, Harvard University"

El-Halaby\&Hussainey. (2015a). The determinants of social accountability dislcosure:Evidence from Islamic banks around the world. IJB Journal.

Elshandidy, T. Fraser, I. and Hussainey, K. (2013). Aggregated, Voluntary, and Mandatory Risk Disclosure Incentives: Evidence from UK FTSE All-share Companies. International Review of Financial Analysis, 30, 320-333 
Elzahar, H. and Hussainey, K. (2012). Determinants of narrative risk disclosures in UK interim Reports. The Journal of Risk Finance, 13 (2), 133-147

Ezat, A. (2010). The key determinants of the voluntary adoption of corporate internet Reporting and its consequences on firm value: Evidence from Egypt. PhD. University of Plymouth, UK

Fama, E. and Jensen, M. (1983). Separation of ownership and control. Journal of Law and Economics, 26 (2), 301-325

Farag, H., Mallin, C., \& Ow-Yong, K. (2014). Corporate social responsibility and financial performance in Islamic banks. Journal of Economic Behavior \& Organization.

Farook, S., Hassan, M. K., \& Lanis, R. (2011). Determinants of Corporate Social Responsibility Dislcosure: The Case of Islmaic Banks. Journal of Islamic Accounting and Business Research, $114-141$.

Garay, U. González, M. Guzmánc, A. and Trujillo, M. (2013). Internet-based corporate Disclosure and market value: Evidence from Latin America. Emerging Markets Review, 17, 150-168

Giraldez, P. and Hurtado JM. (2014), "Do independent Directors protect shareholder value", Business Ethics: A European Review, vol. 23, no. 1, pp. 91-107.

Gisbert, A. and Navallas, B. (2013). The association between voluntary disclosure and Corporate Governance in the Presence of severe agency conflicts. Advances in Accounting, 29 (2), 286-298

Gordon, L. Loeb, M. and Sohail, T. (2010). Market value of voluntary disclosures concerning Information security. MIS Quarterly, 34 (3), 567-940

Gray, R. Owen, D. and Adams, C. (1996). Accounting and Accountability: Changes and Challenges In Corporate Social and Environmental Reporting, London: Prentice Hall.

Gul, F. and Leung, S. (2004). Board leadership, outside directors' expertise and voluntary 
Corporate Disclosure. Journal of Accounting and Public Policy, 23(5), 351-379

Haniffa, R. and Cooke, E. (2005). The impact of culture and governance on corporate social Reporting. Journal of Accounting and Public Policy, 24 (5), 391-430

Haniffa, M. and Cooke, E. (2002). Culture, Corporate Governance and Disclosure in Malaysian Corporations. Abacus, 38, 317-349

Haniffa, R. Hudaib, M. (2007). Exploring the ethical identity of Islamic banks via Communication In annual reports. Journal of Business Ethics, 76, 97-116

Haniffa, R. (1999b). Vol:I-Culture, Corporate Governance And Disclosure In Malaysian Corporations. PhD Thesis. Exeter University.

Hasan, Z. (2011). Shariah Governance In Islamic Financial Institutions In Malaysia,GCC Countries and The UK. Durham University.United Kingdom.

Hashim, H. A., \& Devi, S. S. (2008). Board independence, CEO duality and accrual management: Malaysian evidence. Asian Journal of Business and Accounting, 1(1), 27-46.

Hassan, A. and Harahap, S. (2010). Exploring corporate social responsibility disclosure: the Case of Islamic banks. International Journal of Islamic and Middle Eastern Finance and Management, 3 (3), 203- 227

Hassan, O. Romilly, P. Giorgioni, G. and Power, D. (2009). The value relevance of disclosure: Evidence from the emerging capital market of Egypt. The International Journal of Accounting, 44 (1), 79-102

Hidalgo, 1. Garcia-Meca, E. \& Martinez, I. (2011). Corporate Governance and Intellectual Capital Disclosure. Journal of Business Ethics, 100, 483-495 
Hossain, M. (2008). The Extent of Disclosure in Annual Reports of Banking Companies: The Case of India, 23(4), 659-680.

Hughes, P. (1986). Signalling by direct disclosure under asymmetric information. Journal of Accounting and Economics, 8 (2), 119-142

Hussainey, Elsayed, M. A. R. (2011). Factors Affecting Corporate Social Responsibility Disclosure In Egypt. Corporate Ownership and Control, (July,2011).

IFSB (2018) Islamic Financial Services Industry Stability Report 2018. http://www.ifsb.org/sec03.php [Accessed 19/06/19]

Jo, H. and Harjoto, M. (2011). Corporate Governance and Firm Value: The Impact of Corporate Social Responsibility. Journal of Business Ethics, 103, 351-383

Khan, Fahim, M. and Mario Porzio, (2010), Islamic Banking and Finance in the European Union: A Challenge (U.K., Edward Elgar Publishing Limited).

Klein, P. Shapiro, D. and Young, J. (2005). Corporate governance, family ownership and firm Value: the Canadian evidence. Corporate Governance, 13 (6), 769-84

Laksmana, I. (2008). Corporate board governance and voluntary disclosure of executive Compensation practices. Contemporary Accounting Research, 25 (4), 47-82

Lewis, M. K. (2005). Islamic Corporate Governance, 9(1), 5-29.

Maali, B. Casson, P. and Napier, C. (2006). Social reporting by Islamic banks. Abacus, 42 (2), 266-290

Mallin, C. Faraga, H. and Ow-Yonga, K. (2014). Corporate social responsibility and financial Performance in Islamic banks. Journal of Economic Behaviour and Organization, 103, 21-38 
Mangena, M. and Pike, R. (2005). The effect of audit committee shareholding, financial Expertise and size on interim financial disclosures. Accounting and Business Research, 35 (4), 327-439

MANGENA, M., TAURINGANA, V. and CHAMISA, E., 2012. Corporate boards, ownership structure and firm performance in an environment of severe political and economic crisis. British Journal of Management, 23 (1). ISSN 1467-8551

Mohammed, J. (2007). Corporate social responsibility in Islam. PhD. Auckland University of Technology, Auckland

Olken, B. a., \& Pande, R. (2012). Corruption in Developing Countries. Annual Review of Economics, 4(1), 479-509.

Park, B. Il, \& Ghauri, P. N. (2014). Determinants influencing CSR practices in small and medium sized MNE subsidiaries: A stakeholder perspective. Journal of World Business.

Peng, M. W., Zhang, S., \& Li, X. (2007). CEO Duality and Firm Performance during China's Institutional Transitions. Management and Organization Review, 3(2), 205-225.

Platonova, E. (2013). Corporate Social Responsibility from an Islamic Moral Economy Perspective : A Literature Survey. Afro EUrasian Studies, 2(Issues 1\&2,Spring and Fall 2013), 272-297.

Platonova, E. (2014). Corporate Analysis of CSR Dislcosure and Its Impact on FInancial Performance in the GCC Islamic Banks. Durham University,UK.

Plumlee, M. Brown, D. and Marshall, S., (2009). Voluntary environmental disclosure quality And Firm value: roles of venue and industry type, working study, University of Utah and Portland State University.

Rahman, A. A., \& Bukair, A. A. (2013). The Influence of the Shariah Supervision Board on 
Corporate Social Responsibility Disclosure by Islamic Banks of Gulf Co-Operation Council Countries. Asian Journal of Business and Accounting, 6(2), 65-104.

Rahman, A. A., \& Bukair, A. A. (2015). The effect of the board of directors Characteristics on CSR Dislcosure by Islamic Banks. Asian Journal of Business and Accounting, 6(2), 65-104.

Ramdani, D., \& Witteloostuijn, A. Van. (2010). The impact of board independence and CEO duality on firm performance: A quantile regression analysis for Indonesia, Malaysia, South Korea and Thailand. British Journal of Management, 21(3), 607-627.

Rhodes, M. and Soobaroyen, T. (2010). Information asymmetry and socially responsible Investment. Journal of Business Ethics, 95, 145-150

Samaha, K. Khlif, H. and Hussainey, K. (2015). The Impact of Board Characteristics and Audit Committee on Voluntary Disclosure: A Meta-Analysis. Forthcoming, Journal of International Accounting, Auditing and Taxation (JIAAT), ISSN: 1061-9518, Imprint: Elsevier - USA

Schadewitz, H. and Blevins, D. (1998). Major determinants of interim disclosures in an Emerging Market. American Business Review, 16 (1), 41-55

Schwaiger, M. (2004). Components and parameters of corporate reputation- an empirical Study. Schmalenbach Business Review, 56, 46-71

Servaes, H. and Tamayo, A. (2013). The Impact of Corporate Social Responsibility on Firm Value: The Role of Customer Awareness. Management science, 59 (5), 1045-1061

Sharma, N. (2014). Extent of corporate governance disclosure by banks and finance companies listed on Nepal Stock Exchange. Advances in Accounting, incorporating Advances in International Accounting, 30, 425-439

Sheu, H. Chung, H. and Liu, C. (2010). Comprehensive Disclosure of Compensation and Firm 
Value: The Case of Policy Reforms in an Emerging Market. Journal of Business Finance and Accounting, 37, 1115-1144

Singh, M. Mathur, I. and Gleason, K. (2004). Governance and performance implications of Diversification strategies: evidence from large US firms. Financial Review, 39, 489-526

Soderstrom, N. and Sun, K. (2007). IFRS adoption and accounting quality: A review. The European Accounting Review, 16(4), 675-702

Taha, H. N. (2010). Corporate Social Responsibility Disclosure: An Examination of Framework of Determinants and Consequences. Durham Thesis, Durham University.

Taliyang, S. M., \& Jusop, M. (2011). Intellectual Capital Disclosure and Corporate Governance Structure: Evidence in Malaysia. International Journal of Business and Management, 6(12), 109_ 118

Taylor, G. Tower, G. and Neilson, J. (2010). Corporate communication of financial risk. Accounting and Finance, 50, 417-446

Thompson, P., \& Zakaria, Z. (2004). Corporate Social Responsibility Reporting in Malaysia. Journal of Corporate Citizenship, (13), 125-136.

Tuggle, C. S., Sirmon, D. G., Reutzel, C. R., \& Bierman, L. (2010). Commanding board of director attention: Investigating how organizational performance and CEO duality affect board members' attention to monitoring. Strategic Management Journal, 31(9), 946-968. http://doi.org/10.1002/smj.847

Ullah, M. H. (2013). Compliance of AAOIFI Guidelines in General Presentation and Disclosure in the Financial Statements of Islamic Banks in Bangladesh. International Journal of Social Science Research, 111-123. 
Uyar, A. and Kiliç, M. (2012). Value relevance of voluntary disclosure: evidence from Turkish Firms. Journal of Intellectual Capital, 13 (3), 363-376

Vogel, D. (2005). Is There a Market for Virtue? The Business Case for Corporate Social Responsibility. California Management Review, 47(4), 19-45

Wan Amalina Wan Abdullah, M. P. and J. S. (2009). Corporate Governance Disclosure Practices of Islamic banks: the Case of Islamic banks in the Southeast Asian and the Gulf Cooperation Council region.

Wang, M. and Hussainey, K. (2013). Voluntary forward-looking statements driven by corporate Governance and their value relevance. Journal of accounting and public policy, 32 (3), 26-49

Wang, Q. Wong, J. and Xiac, L. (2008). State ownership, the institutional environment, and Auditor Choice: Evidence from China. Journal of Accounting and Economics, 461, 112-134

Xiao, H. and Yuan, J. (2007). Ownership structure, board composition and corporate voluntary Disclosure: Evidence from listed companies in China. Managerial Auditing Journal, 22 (6), 604 619

Yang, T., Zhao, S., (2013) "CEO Duality and Firm Performance: Evidence from an Exogenous Shock to the Competitive Environment”, Journal of Banking and Finance online 24 April 2014 


\section{Appendix 1: Summary of CSR disclosure dimensions}

\begin{tabular}{|c|c|c|}
\hline Main Dimensions & Sub-Dimensions & Source \\
\hline \multirow{3}{*}{$\begin{array}{l}\text { Social responsibility within } \\
\text { organizations }\end{array}$} & 1. Employee welfare (M) & $\begin{array}{l}\text { AAOIFI, 2010; Vinnicombe, } \\
\text { 2010; Ullah, 2013; Aribi, 2009; } \\
\text { Taha, } 2010\end{array}$ \\
\hline & $\begin{array}{l}\text { 2. Policy for social development } \\
\text { and environment-based } \\
\text { investment quotas. (V) }\end{array}$ & $\begin{array}{l}\text { AAOIFI, 2010; Aribi, 2009; } \\
\text { Aribi \& Gao, } 2012\end{array}$ \\
\hline & $\begin{array}{l}\text { 3. Earning and expenditure } \\
\text { prohibited by Shariah (M) }\end{array}$ & $\begin{array}{l}\text { AAOIFI, 2010; Maali et al., } \\
\text { 2006; Aribi, 2009; Aribi \& Gao, } \\
2012\end{array}$ \\
\hline \multirow{3}{*}{$\begin{array}{l}\text { Social responsibility in its } \\
\text { relationship with customers and } \\
\text { clients }\end{array}$} & $\begin{array}{l}\text { 4. Par excellence customer } \\
\text { services }(V)\end{array}$ & $\begin{array}{l}\text { AAOIFI, 2010; Vinnicombe } \\
\text { 2010; Ullah, 2013; Aribi, 2009; } \\
\text { Taha, } 2010\end{array}$ \\
\hline & $\begin{array}{l}\text { 5. Policy for dealing with } \\
\text { clients (M) }\end{array}$ & $\begin{array}{l}\text { AAOIFI, 2010; Belal et al., } \\
2014\end{array}$ \\
\hline & $\begin{array}{l}\text { 6. Qard-Hassan (benevolent } \\
\text { loan) }(\mathrm{V})\end{array}$ & $\begin{array}{l}\text { AAOIFI, 2010; Vinnicombe, } \\
\text { 2010; Ullah, 2013; Aribi, 2009; } \\
\text { Taha, 2010; Haniffa, } 1999\end{array}$ \\
\hline \multirow{2}{*}{$\begin{array}{l}\text { Social Responsibility in } \\
\text { screening its investments }\end{array}$} & $\begin{array}{l}\text { 7. Micro and small business and } \\
\text { social savings, investments and } \\
\text { development. (V) }\end{array}$ & $\begin{array}{l}\text { AAOIFI, 2010; Maali et al., } \\
\text { 2006; Taha, } 2010\end{array}$ \\
\hline & $\begin{array}{l}\text { 8.Policy for screening clients } \\
\text { (M) }\end{array}$ & $\begin{array}{l}\text { AAOIFI, 2010; Maali et al., } \\
\text { 2006; Aribi, 2009; Aribi \& Gao, } \\
2012\end{array}$ \\
\hline \multirow{3}{*}{$\begin{array}{l}\text { Social responsibility in its } \\
\text { relationship with greater society }\end{array}$} & 9. Zakat $(\mathrm{M})$ & $\begin{array}{l}\text { AAOIFI, 2010; Vinnicombe, } \\
\text { 2010; Ullah, 2013; Aribi, 2009; } \\
\text { Taha, 2010; Haniffa, } 1999\end{array}$ \\
\hline & 10.Charitable activities (V) & $\begin{array}{l}\text { AAOIFI, 2010; Vinnicombe, } \\
\text { 2010; Ullah, 2013; Aribi, 2009; } \\
\text { Taha, } 2010\end{array}$ \\
\hline & $\begin{array}{l}\text { 11.Waqf (endowment) } \\
\text { management }(\mathrm{V})\end{array}$ & $\begin{array}{l}\text { AAOIFI, 2010; Aribi, 2009; } \\
\text { Aribi \& Gao, } 2012\end{array}$ \\
\hline
\end{tabular}




\section{Appendix 2: Summary of variables definitions}

\begin{tabular}{|c|c|c|c|}
\hline Variable & Definition & Measurement & Source \\
\hline CSRD & $\begin{array}{l}\text { Quantity of CSRD score by } \\
\text { sample banks }\end{array}$ & $\begin{array}{l}\text { The percentage of CSR } \\
\text { information disclosure by } \\
\text { Islamic banks }\end{array}$ & Annual Report \\
\hline MTBV & Market-to-book value ratio & $\begin{array}{l}\text { The natural logarithm of } \\
\text { market value of equity to } \\
\text { book value of equity ratio. }\end{array}$ & Data Stream \\
\hline $\mathrm{MC}$ & $\begin{array}{l}\text { Firm value based on market } \\
\text { capitalization }\end{array}$ & $\begin{array}{l}\text { By multiplying a company's } \\
\text { shares outstanding by the } \\
\text { current market price of one } \\
\text { share }\end{array}$ & Data Stream \\
\hline TQ & Tobin's Q & $\begin{array}{l}\text { The natural logarithm of: } \\
\text { (total assets + market value } \\
\text { of equity - total common } \\
\text { equity/ total assets }\end{array}$ & Data Stream \\
\hline B. SIZE & Board size & $\begin{array}{l}\text { The total number of directors } \\
\text { on board }\end{array}$ & Annual Report \\
\hline B. GENDER & Gender of BOD & $\begin{array}{l}\text { A dummy variable equals } 1 \\
\text { if the all boards member of } \\
\text { the firm is male and } 0 \\
\text { otherwise. }\end{array}$ & Annual Report \\
\hline B. COMP & $\begin{array}{l}\text { Board composition } \\
\text { - ratio of exec and non-exec } \\
\text { in the board }\end{array}$ & $\begin{array}{l}\text { The board composition is } \\
\text { calculated as the number of } \\
\text { non-executive directors } \\
\text { divided by board size }\end{array}$ & Annual Report \\
\hline B. MEET & Board meetings & $\begin{array}{l}\text { The total number of board } \\
\text { meetings during the year }\end{array}$ & Annual Report \\
\hline CEO. DUAL & Role of CEO duality & $\begin{array}{l}\text { A dummy variable equals } 1 \\
\text { if the chairman is the same } \\
\text { person as the CEO of the } \\
\text { firm, } 0 \text { otherwise }\end{array}$ & Annual Report \\
\hline B. CROSS & Cross Holding Directorship & $\begin{array}{l}\text { A dummy variable equals } 1 \\
\text { if the Director (regardless of } \\
\text { executive or non-executive) }\end{array}$ & Annual Report \\
\hline
\end{tabular}




\begin{tabular}{|c|c|c|c|}
\hline & & $\begin{array}{l}\text { sits on more than one board, } \\
0 \text { otherwise. }\end{array}$ & \\
\hline SSB SIZE & $\begin{array}{l}\text { Shariah Supervisory Board } \\
\text { size }\end{array}$ & $\begin{array}{l}\text { The total number of Shariah } \\
\text { supervisory board committee }\end{array}$ & Annual Report \\
\hline SSB CROSS & $\begin{array}{l}\text { Shariah supervisory board } \\
\text { cross membership }\end{array}$ & $\begin{array}{l}\text { A dummy variable equals } 1 \\
\text { if the SSB member sits more } \\
\text { than one board and, } 0 \\
\text { otherwise. }\end{array}$ & Annual Report \\
\hline AC SIZE & Audit committee size & $\begin{array}{l}\text { The total number of audit } \\
\text { committee members. }\end{array}$ & Annual Report \\
\hline AC MEET & Audit committee meeting & $\begin{array}{l}\text { The total number of } \mathrm{AC} \\
\text { meetings during the year }\end{array}$ & Annual Report \\
\hline $\mathrm{INS} \mathrm{OWN}^{4}$ & Institutional ownership & $\begin{array}{l}\text { The aggregate percentage of } \\
\text { shares that are held by } \\
\text { institutional shareholders. }\end{array}$ & $\begin{array}{l}\text { Annual Report } \\
\text { /DataStream/ }\end{array}$ \\
\hline FOR OWN & Foreign Ownership & $\begin{array}{l}\text { The aggregate percentage of } \\
\text { shares that hold by foreign } \\
\text { shareholders. }\end{array}$ & $\begin{array}{l}\text { Annual Report } \\
\text { /DataStream }\end{array}$ \\
\hline F. SIZE & Firm size & $\begin{array}{l}\text { The natural logarithm of } \\
\text { firms' total assets. }\end{array}$ & Data stream \\
\hline F. AGE & Firm age & The age of the firm & Data stream \\
\hline F. PROFIT & Profitability & $\begin{array}{l}\text { The profitability measured } \\
\text { by return on equity }\end{array}$ & Data stream \\
\hline F. LEV & Leverage & $\begin{array}{l}\text { The ratio of total debt/total } \\
\text { equity. }\end{array}$ & $\begin{array}{l}\text { Data } \\
\text { stream/Annual } \\
\text { report }\end{array}$ \\
\hline F. LIQUID & Liquidity & $\begin{array}{l}\text { Current assets/Current } \\
\text { liabilities }\end{array}$ & Data stream \\
\hline GDP & Growth domestic products & GDP of the sample countries & World Bank \\
\hline Corruption & Corruption rate & $\begin{array}{l}\text { Corruption rate of the sample } \\
\text { countries }\end{array}$ & $\begin{array}{l}\text { Transparency } \\
\text { index }\end{array}$ \\
\hline
\end{tabular}

\footnotetext{
${ }^{4}$ In collecting the data for INS OWN and FOR OWN, a few source of information is analysed in measuring the aggregate percentage of shares hold by institutional/foreign shareholders in companies annual reports and data stream.
} 